\begin{tabular}{|c|c|c|c|c|c|c|c|c|c|c|}
\hline IIM & MSA & ILD & Arthritis & Arthralgia & Myositis & Raynauds & Cutanous & Malignancy & Final diagnosis & Treatment Outcome \\
\hline & NXP2 & & & & + & & + & & $\begin{array}{l}\text { Dermatomyositis } \\
\text { Myasthenia gravis }\end{array}$ & $\begin{array}{l}\text { Prednisolone + IVIG Remission/stable } \\
+ \text { Azathioprine + } \\
\text { pyridostigmine }\end{array}$ \\
\hline & MDA5 & & & + & & & + & & Amyopathic dermatomyositis & Prednisolone + MTX Remission/stable \\
\hline & SAE1 & & & & + & & + & & Dermatomyositis & Prednisolone + MTX Remission/stable \\
\hline ILD & PL12 & + & & & & & & & IPF & No medication Remission/stable \\
\hline \multirow[t]{4}{*}{ Ro52 } & PL12 & + & & & & & & & IPF & Prednisolone Died \\
\hline & $\begin{array}{l}\text { SAE1/ } \\
\text { OJ }\end{array}$ & + & & & & & & & IPF & No medication Lost follow-up \\
\hline & EJ & + & & & & & & & IPF & No medication Remission/stable \\
\hline & PL12 & + & & & & & & & $\begin{array}{l}\text { Interstitial pneumonia with autoimmune } \\
\text { feature (IPAF) }\end{array}$ & Under evaluation Remission/stable \\
\hline \multirow[t]{4}{*}{ Ro52 } & PL7 & + & + & + & & + & + & & Anti-synthetase syndrome & $\begin{array}{l}\text { Prednisolone }+ \\
\text { cyclophosphamide Remission/stable } \\
\text { then azathioprine }\end{array}$ \\
\hline & PL7 & + & & & + & & & & Anti-synthetase syndrome & Prednisolone + Remission/stable \\
\hline & & & & & & & & & & Rituximab \\
\hline & $\mathrm{JO}-1$ & + & & & & + & & & Anti-synthetase syndrome & No medication Remission/stable \\
\hline Ro52 & JO-1 & + & & & & & & & Anti-synthetase syndrome & $\begin{array}{l}\text { Prednisolone + MMF Remission/stable } \\
\text { then rituximab }\end{array}$ \\
\hline \multirow[t]{3}{*}{ CTD } & SAE1/ & + & & & & & & + & $\begin{array}{l}\text { Progressive pulmonary fibrosis (post COVID, } \\
\text { ARDS and recurrent aspiration) }\end{array}$ & $\begin{array}{l}\text { Antibiotics + } \\
\text { supportive care Remission/stable }\end{array}$ \\
\hline & SRP & & & & & & & & Esophageal Ca T1N2M0 s/p esophagectomy & \\
\hline & SRP & & & & & + & + & & Limited cutaneous scleroderma & Nifedipine Remission/stable \\
\hline Ro52 & EJ & & & + & & & & & Sjogren & HCQ Remission/stable \\
\hline Others & OJ & & + & + & + & & + & & MCTD & Prednisolone+ Remission/stable \\
\hline \multirow{3}{*}{$\begin{array}{l}\text { U1snRNP/ } \\
\text { Ro52 }\end{array}$} & & & & & & & & & Autoimmune hepatitis & Azathioprine+HCQ \\
\hline & & & & & & & & & & \\
\hline & NXP2 & & & + & & & & & Polymyalgia rheumatica & Prednisolone Remission/stable \\
\hline \multirow[t]{3}{*}{ ku } & $\mathrm{Mi} 2 \mathrm{~b}$ & & & + & & & & & large vessel vasculitis & $\begin{array}{l}\text { Prednisolone+ Remission/stable } \\
\text { Tocilizumab }\end{array}$ \\
\hline & PL12 & & + & + & & & + & & PsA & MTX Remission/stable \\
\hline & $\mathrm{Mi} 2 \mathrm{~b}$ & & & & & & & & PBC & $\begin{array}{l}\text { Ursodeoxycholic acid Remission/ } \\
\text { stable }\end{array}$ \\
\hline
\end{tabular}

Disclosure of Interests: None declared

DOI: 10.1136/annrheumdis-2021-eular.184

\section{AB0405 FIBROBLAST GROWTH FACTOR-23 IS ASSOCIATED WITH HIGH-DENSITY LIPOPROTEIN IN SYSTEMIC SCLEROSIS PATIENTS}

A. Alvarez de Cienfuegos ${ }^{1}$, L. Cantero-Nieto ${ }^{2}$, J. A. García-Gómez ${ }^{3}$, R. Ríos Fernández ${ }^{4}$, J. Martin Ibanez ${ }^{5}$, M. A. González-Gay ${ }^{6}$, N. Ortego ${ }^{4} .{ }^{1}$ Hospital Vega-Baja, Department of Rheumatology, Alicante, Spain; ${ }^{2}$ Hospital Santa Ana, Department of Emergency, Granada, Spain; ${ }^{3}$ Hospital General de Elche, Infectious Diseases Unit, Alicante, Spain; ${ }^{4}$ Hospital Universitario San Cecilio, Systemic Autoimmune Diseases Unit, Granada, Spain; ${ }^{5} I P B L N-C S I C$, Institute of Parasitology and Biomedicine López-Neyra, Granada, Spain; ${ }^{6}$ University of Cantabria, School of Medicine, Santander, Spain

Background: Systemic sclerosis (SSc) is characterized by calcification, vasculopathy, and endothelial wall damage, all of which can increase the risk for atherosclerosis and cardiovascular disease. Mechanisms by which atherosclerosis is promoted in connective tissue diseases remain unknown, but is believed to be secondary to chronic inflammation, altered lipid profiles and function, autoantibodies, and endothelial dysfunction. Fibroblast growth factor-23 (FGF23) is a circulating regulator of phosphate and vitamin D metabolism and has been implicated as a putative pathogenic factor in cardiovascular disease. FGF23 could exert hormonal control on fat mass and glucose metabolism, since it shares structural similarities with the other FGF subfamily members (FGF15/19 and FGF21) that are involved in carbohydrate and lipid metabolism.

Objectives: The objectives of this study were: to compare serum FGF23 levels between SSc patients and healthy controls and to investigate possible associations between FGF23 and serum lipid profile in SSc patients.

Methods: This cross-sectional study was performed in San Cecilio Hospital, Granada (Spain) from November 2017 to May 2019. Sixty-two women with SSc and 62 age and sex matched healthy controls were enrolled in this study. All patients included in this study had normal serum creatinine $(\mathrm{Cr})$ levels and met the 2013 American College of Rheumatology/European League Against Rheumatism (ACR/EULAR) criteria for SSc. Total cholesterol and triglyceride levels were determined by fully enzymatic techniques. High-density lipoprotein (HDL) was determined after precipitation of apolipoprotein B (apoB)-containing lipoproteins with magnesium sulfate and dextran sulfate. Low-density lipoprotein (LDL) was calculated using the Friedewald formula. Serum FGF23 was analyzed using ELISA.
Results: A total of 62 female patients were included in our study, with a mean (SD) age of $53 \pm 10$ years. The majority were Caucasian (90.5\%). The mean disease duration was $8.8 \pm 6.9$ years. Forty-four $(70.9 \%)$ patients had a limited form of the disease and $18(29.1 \%)$ had a diffuse form.

There was no significant differences in FGF23 levels between the patients and controls $(78.2 \pm 60.5$ vs. $80.3 \pm 56.3 \mathrm{pg} / \mathrm{mL}, p=0.662)$, but we found a statistically significant inverse relationship between FGF23 and HDL-c measurements $(r=-0.27 ; p=0.03)$ in women with SSc. In addition, in the linear regression model, higher FGF23 concentrations were associated with lower HDL-c $[\beta=-1.4595 \%$ $\mathrm{Cl}(-2.81,-0.08) ; \mathrm{p}<0.05]$.

Conclusion: We report an association between circulating FGF23 and HDL-C in SSc female patients, representing a novel pathway linking high FGF23 to an increased cardiovascular risk.

REFERENCES:

[1] Ho M, Veale D, Eastmond C, et al. Macrovascular disease and systemic sclerosis. Ann Rheum Dis. 2000; 59(1):39-43.

[2] McMahon M, Grossman J, FitzGerald J, et al. Proinflammatory high-density lipoprotein as a biomarker for atherosclerosis in patients with systemic lupus erythematosus and rheumatoid arthritis. Arthritis Rheum. 2006; 54(8):2541-9.

[3] O'Neill SG, Giles I, Lambrianides A, et al. Antibodies to apolipoprotein A-I, high-density lipoprotein, and C-reactive protein are associated with disease activity in patients with systemic lupus erythematosus. Arthritis Rheum. 2010; 62(3):845-54.

[4] Mirza MA, Alsio J, Hammarstedt A, et al. Circulating fibroblast growth factor-23 is associated with fat mass and dyslipidemia in two independent cohorts of elderly individuals. Arterioscler Thromb Vasc Biol. 2011; 31:219-227.

Disclosure of Interests: None declared

DOI: 10.1136/annrheumdis-2021-eular.302

\section{AB0406 ASSOCIATION OF ENDOTHELIN-1 WITH PULSE WAVE VELOCITY IN SYSTEMIC SCLEROSIS PATIENTS}

A. Alvarez de Cienfuegos ${ }^{1}$, L. Cantero-Nieto ${ }^{2}$, J. A. García-Gómez ${ }^{3}$, J. L. Callejas-Rubio ${ }^{4}$, J. Martin Ibanez ${ }^{5}$, N. Ortego ${ }^{4} .{ }^{1}$ Hospital Vega-Baja, Department of Rheumatology, Alicante, Spain; ${ }^{2}$ Hospital Santa Ana, Department of Emergency, Granada, Spain; ${ }^{3}$ Hospital General de Elche, Infectious Diseases Unit, Alicante, Spain; ${ }^{4}$ Hospital Universitario San Cecilio, Systemic Autoimmune Diseases Unit, Granada, Spain; ${ }^{5}$ IPBLN-CSIC, Institute of Parasitology and Biomedicine López-Neyra, Granada, Spain

Background: Systemic sclerosis (SSc) is a multisystemic disease featured by vascular and immunological disorders along with an excessive accumulation of the components of the connective tissue that cause cutaneous sclerosis and 